\title{
Peningkatan Perolehan Uranium, Torium, dan Logam Tanah Jarang Dalam Residu Pelarutan Parsial pada Pengolahan Monasit
}

\section{Increasing Recovery of Uranium, Thorium, and Rare Earth Metals Within Partial Dissolution Residue on Monazite Processing}

\author{
Novita Sari Fatihah ${ }^{1 *}$, Mutia Anggraini ${ }^{2}$, Afiq Azfar Pratama ${ }^{2}$, Kurnia Setiawan Widana ${ }^{2}$ \\ ${ }^{1}$ UIN Syarif Hidayatullah Jakarta \\ Jl. Ir. H. Juanda, Ciputat, Tangerang Selatan, Banten 15412, Indonesia \\ ${ }^{2}$ Pusat Riset dan Teknologi Bahan Galian Nuklir - ORTN-BRIN \\ J1. Lebak Bulus Raya 9, Pasar Jumat, Jakarta 12440, Indonesia \\ *E-mail: novitasarifatihah@gmail.com
}

Naskah diterima: 12 Oktober 2020, direvisi: 2 November 2020, disetujui: 5 November 2021 DOI: 10.17146/eksplorium.2021.42.2.6044

\begin{abstract}
ABSTRAK
Monasit merupakan mineral hasil samping pengolahan timah yang mengandung fosfat, logam tanah jarang, dan unsur radioaktif berupa uranium dan torium. Unsur-unsur tersebut dapat dimanfaatkan secara optimal jika terpisah satu dengan yang lainnya melalui proses pengolahan. Pengolahan monasit meliputi proses dekomposisi, pelarutan parsial, dan pengendapan. Pemisahan unsur logam tanah jarang dari unsur radioaktif dalam monasit dilakukan melalui proses pelarutan parsial, akan tetapi pemisahan tersebut belum optimal sehingga diperlukan proses lebih lanjut untuk meningkatkan perolehan unsur-unsur tersebut. Pada penelitian ini, proses tersebut dilakukan melalui dua metode yaitu pelarutan total dengan asam klorida $(\mathrm{HCl})$ yang bertujuan untuk melarutkan semua unsur dalam endapan dan pengendapan dengan ammonium hidroksida $\left(\mathrm{NH}_{4} \mathrm{OH}\right)$ yang bertujuan untuk memisahkan unsur radioaktif dan unsur logam tanah jarang. Kedua metode tersebut dilakukan pada kondisi optimum proses dengan berbagai variasi $\mathrm{pH}$, suhu, dan waktu. Berdasarkan hasil pengamatan diperoleh bahwa kelarutan optimum masing-masing unsur sebesar 67,6\% uranium, 15,3\% torium, dan 50,8\% LTJ pada kondisi proses pelarutan $\mathrm{pH} 1$, pada suhu $80^{\circ} \mathrm{C}$ selama 2 jam. Sedangkan pada proses pengendapan diperoleh recovery pengendapan masing-masing unsur sebesar 57\% uranium, 75,7\% torium, 4,8\% logam tanah jarang pada kondisi $\mathrm{pH}$ 6. Berdasarkan data tersebut disimpulkan bahwa uranium, torium, dan logam tanah jarang dapat larut pada kondisi proses pelarutan $\mathrm{pH} 1$, suhu $80^{\circ} \mathrm{C}$ selama 2 jam, dan dapat dipisahkan pada kondisi pH pengendapan 6 .
\end{abstract}

Kata kunci: Logam tanah jarang, monasit, pelarutan total, pengendapan, torium, uranium.

\begin{abstract}
Monazite is a by-product of tin processing containing phosphate, rare earth elements, and radioactive elements such as uranium and thorium. These elements can be utilized optimally if separated from one another through processing. Monazite processing includes decomposition, partial dissolution, and precipitation processes. The separation of rare earth elements from radioactive elements in monazite is carried out through a partial dissolution process, but the separation is not optimal so that further processes are needed to increase the recovery of these elements. In this study, the process was carried out using two methods, namely total dissolution with hydrochloric acid $(\mathrm{HCl})$ which aims to dissolve all elements in the precipitate and precipitation with ammonium hydroxide $(\mathrm{NH} 4 \mathrm{OH})$ which aims to separate radioactive elements and rare earth elements. Both methods were carried out under optimum process conditions with various variations in $\mathrm{pH}$, temperature, and time. Based on observations, it was found that the optimum solubility of each element was $67.6 \%$ uranium, $15.3 \%$ thorium and $50.8 \%$ LTJ under the dissolving process conditions of $\mathrm{pH} 1$, at $80^{\circ} \mathrm{C}$ for 2 hours. While in the deposition process, the precipitation recovery of each element is $57 \%$ uranium, $75.7 \%$ thorium, $4.8 \%$ rare earth metals at pH 6
\end{abstract}


conditions. Based on these data, it can be concluded that uranium, thorium, and rare earth elements can be dissolved at $\mathrm{pH} \mathrm{1,} \mathrm{at} 80^{\circ} \mathrm{C}$ for 2 hours, and can be separated at $\mathrm{pH} 6$ precipitation conditions.

Keywords: Rare earth elements, monazite, total dissolution, precipitation, thorium, uranium.

\section{PENDAHULUAN}

Monasit merupakan mineral ikutan hasil pengolahan timah yang mengandung unsurunsur bernilai ekonomi tinggi seperti uranium (U), torium (Th), logam tanah jarang (LTJ), dan fosfat $\left(\mathrm{PO}_{4}\right)$ dengan rumus kimia $(\mathrm{U}, \mathrm{Th}$, LTJ) $\mathrm{PO}_{4}[1]$. Monasit memiliki kandungan unsur LTJ sebesar $50-67 \%$, U sebesar 0,15 0,3\%, Th sebesar 2,5-3,6\%, dan $\mathrm{PO}_{4}$ sebesar $18-30 \%$ [2]. Unsur-unsur tersebut dapat dimanfaatkan sesuai fungsinya jika telah dipisahkan satu dengan yang lainnya. Oleh karena itu, pengolahan terhadap monasit perlu dilakukan untuk memisahkan unsur-unsur tersebut.

Pengolahan monasit di PTBGN BATAN dilakukan melalui metode basa dengan tahapan antara lain dekomposisi, pelarutan parsial, pengendapan uranium dan torium hidroksida, serta pengendapan logam tanah jarang hidroksida [3]. Dekomposisi dilakukan untuk menghilangkan fosfat yang terkandung dalam monasit [3]. Endapan hasil proses dekomposisi selanjutnya masuk dalam tahap pelarutan parsial. Pelarutan parsial bertujuan untuk melarutkan logam tanah jarang, sehingga dihasilkan LTJ dalam larutan dan unsur radioaktif, berupa uranium dan torium, pada endapan. Endapan yang dihasilkan melalui proses pelarutan parsial masih mengandung LTJ dengan kadar 39,9\% [4] sehingga diperlukan proses kimia yang dapat memisahkan unsur radioaktif dan LTJ pada endapan hasil pelarutan parsial sehingga uranium, torium, dan LTJ yang diperoleh dapat optimal.
Penelitian ini bertujuan untuk mencari kondisi optimal proses pemisahan uranium, torium, dan logam tanah jarang yang masih berada pada endapan pelarutan parsial. Metode yang digunakan pada penelitian ini adalah pelarutan total dan pengendapan. Pelarutan total dilakukan untuk melarutkan semua unsur dalam endapan sedangkan pengendapan dilakukan untuk memisahkan unsur radioaktif dan LTJ yang telah dilarutkan. Penentuan kondisi optimum proses pelarutan total dilakukan berdasarkan variasi kondisi $\mathrm{pH}$, suhu, dan waktu. Pada proses pengendapan hanya parameter $\mathrm{pH}$ yang diamati, parameter waktu dan suhu tidak diamati karena tidak memberikan pengaruh yang besar terhadap proses pengendapan [5].

\section{TEORI}

Monasit di Indonesia berasal dari daerah yang berbeda seperti Monasit Bangka, Monasit Rirang, dan Monasit Kalimatan [6]. Setiap monasit dari daerah yang berbeda memiliki karakteristik senyawa yang berbeda. Unsur-unsur dalam monasit memiliki nilai ekonomis yang tinggi sehingga banyak dimanfaatkan di bidang industri nuklir maupun non nuklir [1]. Oleh sebab itu, perlu dilakukan pengolahan monasit untuk memperoleh unsur-unsur tersebut.

Pengolahan monasit dapat dilakukan melalui beberapa metode, yaitu metode asam dan metode basa [7]. Metode asam yaitu pelindian menggunakan asam kuat, umumnya lebih disukai menggunakan asam sulfat $\left(\mathrm{H}_{2} \mathrm{SO}_{4}\right)$, karena asam sulfat memiliki daya larut dan titik didih yang tinggi. Kekurangan 
metode asam adalah fosfat yang berada pada monasit tidak terpisah dari uranium, torium, dan logam tanah jarang karena tidak melalui proses dekomposisi, melainkan monasit secara langsung dilarutkan menggunakan asam kuat [8]. Metode basa yaitu pelindian menggunakan basa kuat. Senyawa yang banyak digunakan adalah sodium hidroksida $(\mathrm{NaOH})[9]$.

Pada pengolahan monasit secara basa dikenal istilah dekomposisi. Dekomposisi dilakukan untuk memutuskan ikatan fosfat pada monasit sehingga monasit berganti ikatan menjadi hidroksida menggunakan reagen basa kuat $\mathrm{NaOH}[10]$. Reaksi dekomposisi adalah sebagai berikut:

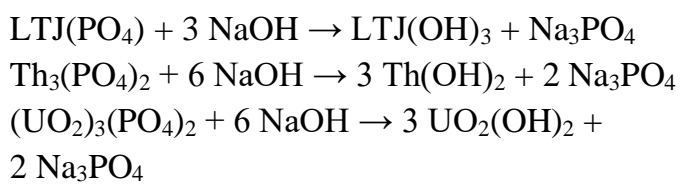

Endapan hasil proses dekomposisi yang berupa uranium, torium, dan logam tanah jarang hidroksida selanjutnya dilarutkan secara parsial. Pelarutan parsial bertujuan untuk melarutkan logam tanah jarang sebanyak mungkin dan uranium dan torium yang terlarut seminimal mungkin[4]. Pelarutan parsial umumnya dilakukan dalam kondisi asam menggunakan reagen $\mathrm{HCl}, \mathrm{H}_{2} \mathrm{SO}_{4}$, atau $\mathrm{HNO}_{3}$, dengan mengontrol $\mathrm{pH}$ pada kisaran 3 4. Unsur logam tanah jarang terlarut ke dalam asam, sedangkan torium dan uranium sedikit terlarut pada kondisi $\mathrm{pH}$ tersebut[11]. Reaksi yang terjadi pada proses pelarutan parsial adalah sebagai berikut:

$$
\begin{aligned}
& \mathrm{LTJ}(\mathrm{OH})_{3}+3 \mathrm{HCl} \rightarrow \mathrm{LTJCl}_{3}+3 \mathrm{H}_{2} \mathrm{O} \\
& \mathrm{Th}(\mathrm{OH})_{4}+4 \mathrm{HCl} \rightarrow \mathrm{ThCl}_{4}+4 \mathrm{H}_{2} \mathrm{O} \\
& \mathrm{UO}_{2}(\mathrm{OH})_{2}+2 \mathrm{HCl} \rightarrow \mathrm{UO}_{2} \mathrm{Cl}_{2}+2 \mathrm{H}_{2} \mathrm{O}
\end{aligned}
$$

Proses pelarutan parsial menghasilkan filtrat dan endapan. Filtrat mengandung LTJ yang sebagian besar terlarut serta sedikit uranium dan torium yang ikut terlarut, sedangkan pada endapan pelarutan parsial terdapat uranium, torium, dan logam tanah jarang yang masih mengendap.

\section{METODOLOGI}

\section{Preparasi}

Preparasi dilakukan pada residu pelarutan parsial atau umpan yang berasal dari Pilot Plant PLUTHO berupa bongkahan berwarna kehijauan. Umpan digerus sampai halus, kemudian disaring menggunakan siever ukuran -230 mesh. Umpan ditimbang sebanyak 100 gram untuk satu kali proses pelarutan. Analisis uranium, torium, dan logam tanah jarang dilakukan pada umpan untuk mengetahui kadar unsur tersebut pada umpan awal.

\section{Pelarutan Total}

Pelarutan total dilakukan dengan cara memasukkan 100 gram umpan ke dalam gelas beaker dan menambahkan air sebanyak 200 $\mathrm{mL}$. Larutan tersebut kemudian diaduk hingga larut dan diukur nilai $\mathrm{pH}$ awal larutan menggunakan $\mathrm{pH}$ meter. $\mathrm{HCl}$ kemudian ditambahkan setetes demi setetes pada larutan tersebut dan $\mathrm{pH}$ diukur hingga mencapai $\mathrm{pH} 1$, 2, 3, dan 4. Larutan umpan pada $\mathrm{pH}$ tersebut diatur dengan 4 variasi suhu, yaitu suhu tanpa pemanasan, 50,80 , dan $90^{\circ} \mathrm{C}$, dan waktu pelarutan terdiri dari 1, 2, dan 3 jam.

Proses pelarutan tersebut menghasilkan slurry yang selanjutnya diencerkan dengan $\mathrm{HCl}$ pada $\mathrm{pH}$ yang disesuaikan seperti saat proses pelarutan total sebanyak $100 \mathrm{~mL}$. Larutan kemudian disaring untuk memisahkan filtrat dan endapan dari proses pelarutan total. Analisis kadar uranium dan torium dilakukan pada filtrat dan endapan tersebut menggunakan Spektrofotometer UV-Vis sedangkan analisis logam tanah jarang dilakukan menggunakan Indutively Couple Plasma - Optical Emission Spektrofotometer 
(ICP-OES). Filtrat pelarutan total digunakan sebagai umpan untuk proses pengendapan.

\section{Pengendapan}

Filtrat pelarutan total pada kondisi optimal ditambahkan $\mathrm{NH}_{4} \mathrm{OH}$ setetes demi setetes hingga $\mathrm{pH}$ sesuai dengan variasi, yaitu $\mathrm{pH}$ 5, 6, dan 7. Hasil pengendapan berupa filtrat dan endapan yang dipisahkan melalui proses filtrasi. Analisis kadar uranium dan torium dilakukan pada filtrat dan endapan dengan Spektrofotometer UV-Vis sedangkan analisis logam tanah jarang dilakukan dengan ICP-OES.

\section{HASIL DAN PEMBAHASAN}

Uranium, torium, dan LTJ yang masih terkandung dalam endapan hasil pelarutan parsial dilarutkan kembali melalui proses pelarutan total. Berdasarkan analisis dengan ICP-OES dan Spektrofotometer UV-Vis diperoleh kadar uranium, torium, dan LTJ dalam endapan hasil pelarutan parsial masingmasing sebesar $0,28 \% \mathrm{U}, 0,42 \% \mathrm{Th}$, dan $77,7 \%$ LTJ. Melalui proses pelarutan total, unsur-unsur tersebut dapat larut dalam kondisi optimal proses yang selanjutnya akan diendapkan berdasarkan $\mathrm{pH}$ tertentu sehingga LTJ dapat terpisah dari U dan Th. Penentuan kondisi optimal proses pelarutan total ditentukan melalui pengamatan kelarutan uranium, torium, dan LTJ terhadap variasi $\mathrm{pH}$, suhu, dan waktu.

Pengamatan variasi $\mathrm{pH}$ terhadap kelarutan uranium, torium, dan LTJ dilakukan terlebih dahulu karena kondisi $\mathrm{pH}$ larutan memberikan pengaruh yang besar dibandingkan suhu dan waktu. Berdasarkan hasil pengamatan parameter $\mathrm{pH}$ pada proses pelarutan total yang dilakukan pada suhu $80^{\circ} \mathrm{C}$ selama 2 jam, terjadi perubahan warna larutan seperti terlihat pada Gambar 1.

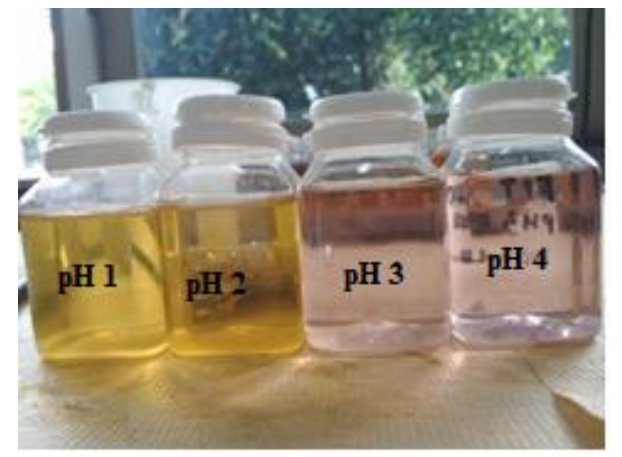

Gambar 1. Filtrat pelarutan total parameter $\mathrm{pH}$ (dari kiri ke kanan, filtrat pelarutan $\mathrm{pH} 1,2,3$, dan 4).

Warna kuning merupakan salah satu ciri fisik dari uranium dalam bentuk ion uranil yang terlarut dalam pelarut asam [12]. Filtrat pelarutan $\mathrm{pH} 1$ dan 2 berwarna kuning karena jumlah uranium yang terlarut lebih banyak dibandingkan dengan filtrat pelarutan $\mathrm{pH} 3$ dan 4. Warna merah muda pada filtrat pelarutan $\mathrm{pH} 3$ dan $\mathrm{pH} 4$ mengindikasikan adanya kandungan logam tanah jarang yang lebih banyak terlarut, dalam hal ini merupakan indikasi cerium oksida[12]. Torium dan uranium tidak terlarut pada kondisi $\mathrm{pH} 3-4$, sehingga keberadaannya pada filtrat pelarutan pH 3 dan pH 4 cenderung lebih sedikit[11]. Hal tersebut dibuktikan dari hasil recovery uranium, torium, dan logam tanah jarang pada Gambar 2.

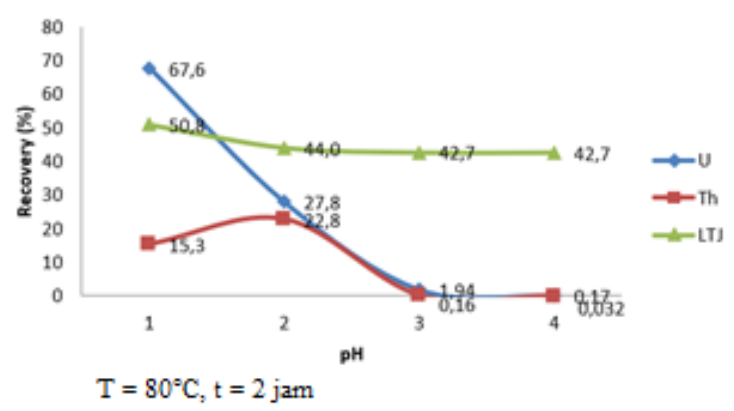

Gambar 2. Hasil recovery uranium, torium, dan logam tanah jarang pada filtrat pelarutan total parameter $\mathrm{pH}$.

Gambar 2 menunjukkan fluktuasi pada persentase recovery uranium, torium, dan logam tanah jarang. Persentase recovery uranium menurun seiring dengan 
bertambahnya $\mathrm{pH}$. Persentase recovery uranium menunjukkan nilai paling tinggi pada $\mathrm{pH}$ 1. Uranium dalam filtrat pelarutan berada dalam bentuk uranil pada rentang $\mathrm{pH}(1<\mathrm{pH}<$ 2). Konsentrasi uranil akan semakin meningkat dengan menurunnya $\mathrm{pH}[13]$.

Grafik recovery torium mengalami kenaikan dari $\mathrm{pH} 1$ ke $\mathrm{pH} 2$ dan kembali menurun seiring bertambahnya $\mathrm{pH}$. Hal ini sejalan dengan literatur yang menyatakan bahwa torium pada $\mathrm{pH}>2$ berada sebagai senyawa hidroksida dan pada $\mathrm{pH}<2$ berada dalam bentuk ionnya[11]. Torium (IV) ionik terlarut pada lingkungan yang sangat asam[14] sehingga keberadaannya pada $\mathrm{pH} 3$ dan 4 tidak stabil dan menyebabkan kelarutan torium semakin menurun. Hal ini menyebabkan persentase recovery torium pada filtrat pelarutan total $\mathrm{pH} 3$ dan $\mathrm{pH} 4$ menurun. Hasil penelitian menyatakan bahwa kelarutan torium berada pada kondisi sangat asam dengan rentang $\mathrm{pH} 1-2$.

Grafik recovery logam tanah jarang semakin menurun disertai dengan meningkatnya $\mathrm{pH}$. Puncak tertinggi berada pada $\mathrm{pH}$ 1, walaupun perbedaan recovery antar $\mathrm{pH}$ tidak terlalu signifikan. Hal ini dapat terjadi karena ion logam tanah jarang dalam bentuk kation $3^{+}$stabil pada $\mathrm{pH}$ yang asam hingga $\mathrm{pH}$ 6, kemudian membentuk fase solid $\mathrm{RE}(\mathrm{OH})_{3}$ seiring dengan meningkatnya $\mathrm{pH}[14]$. Kenaikan $\mathrm{pH}$ pada proses pelarutan menyebabkan stabilitas ion logam tanah jarang semakin menurun sehingga keberadaannya pada filtrat pelarutan total $\mathrm{pH}>1$ semakin menurun.

Berdasarkan persentase recovery pelarutan total parameter $\mathrm{pH}$ dapat disimpulkan secara umum uranium, torium, dan logam tanah jarang, dapat larut pada kondisi asam sehingga keberadaan unsurunsur tersebut terdistribusi pada filtrat pelarutan total $\mathrm{pH} 1$ (FPT $\mathrm{pH}$ 1). Oleh karena itu, dapat disimpulkan bahwa kondisi optimal pelarutan total parameter $\mathrm{pH}$ adalah $\mathrm{pH} 1$.

Parameter yang diamati selanjutnya adalah suhu. Pelarutan total parameter suhu dilakukan dengan memvariasikan suhu pada kondisi $\mathrm{pH}$ optimal yaitu $\mathrm{pH} 1$ dan waktu 2 jam. Hasil filtrat pelarutan total parameter suhu ditunjukkan pada Gambar 3.

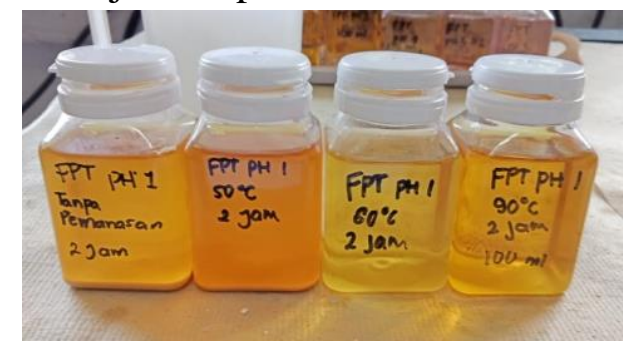

Gambar 3. Filtrat pelarutan total parameter suhu.

Berdasarkan gambar di atas terlihat bahwa suhu mempengaruhi warna dan kejernihan filtrat. Filtrat tanpa pemanasan berwarna kuning keruh dan terdapat endapan, filtrat $50^{\circ} \mathrm{C}$ berwarna kuning pekat sedikit keruh namum tidak terdapat endapan, filtrat $80^{\circ} \mathrm{C}$ berwarna kuning cerah dan jernih, dan filtrat $90^{\circ} \mathrm{C}$ berwarna kuning pekat yang jernih. Semakin tinggi suhu, maka semakin jernih filtrat yang dihasilkan. Hal ini mengindikasikan suhu yang tinggi dapat meningkatkan pelarutan menjadi lebih sempurna. Selain warna, perbedaan suhu juga mempengaruhi unsur-unsur yang terlarut. Hal ini ditunjukkan dari grafik recovery uranium, torium, dan logam tanah jarang pada Gambar 4.

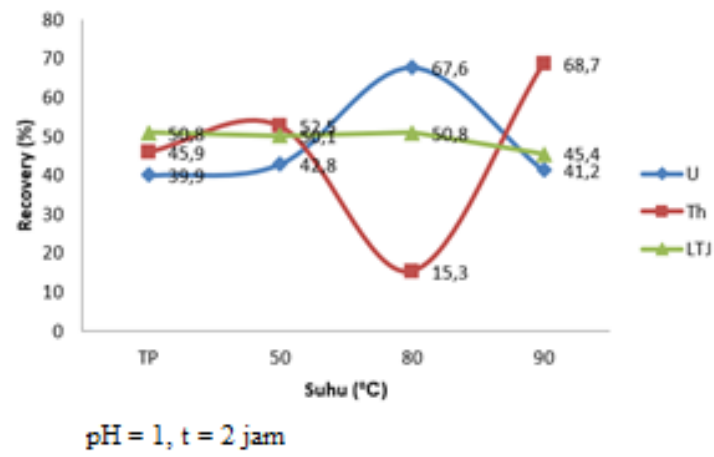

Gambar 4. Hasil recovery uranium, torium, dan logam tanah jarang pada filtrat pelarutan total parameter suhu. 
Recovery uranium mengalami fluktuasi. Terjadi peningkatan persentase recovery uranium pada kondisi proses tanpa pemanasan hingga suhu $80^{\circ} \mathrm{C}$. Peningkatan suhu akan mempercepat reaksi tumbukan antara pelarut dan zat terlarut, sehingga dalam hal ini uranium akan lebih mudah terlarut pada suhu yang tinggi. Namun, pada suhu $90^{\circ} \mathrm{C}$ terjadi penurunan recovery uranium. Hal ini terjadi karena adanya penguapan pelarut sehingga secara stoikiometri jumlah $\mathrm{HCl}$ yang akan melarutkan unsur dalam endapan berkurang [15] dan mengakibatkan uranium tidak bereaksi sempurna dengan $\mathrm{HCl}$. Grafik recovery torium menunjukkan fluktuasi yang cukup signifikan, data pada pelarutan tanpa pemanasan hingga suhu $50^{\circ} \mathrm{C}$ menunjukkan kenaikan. Pada suhu $80^{\circ} \mathrm{C}$ persentase recovery mengalami penurunan yang signifikan dan kembali naik pada suhu $90^{\circ} \mathrm{C}$. Berdasarkan pengamatan tersebut maka kondisi suhu optimal untuk melarutkan uranium dan torium dalam endapan hasil pelarutan parsial adalah $80-90^{\circ} \mathrm{C}$. Grafik recovery logam tanah jarang tidak mengalami penurunan ataupun peningkatan recovery yang signifikan. Hal ini terjadi karena pada $\mathrm{pH}$ dan suhu tersebut reaksi antara LTJ dan $\mathrm{HCl}$ belum optimal.

Pelarutan total parameter waktu ditentukan dengan memvariasikan waktu pelarutan menggunakan kondisi $\mathrm{pH}$ dan suhu yang optimal, yaitu $\mathrm{pH} 1$ dan suhu $80^{\circ} \mathrm{C}$. Pelarutan total parameter ini menghasilkan warna filtrat pada Gambar 5.

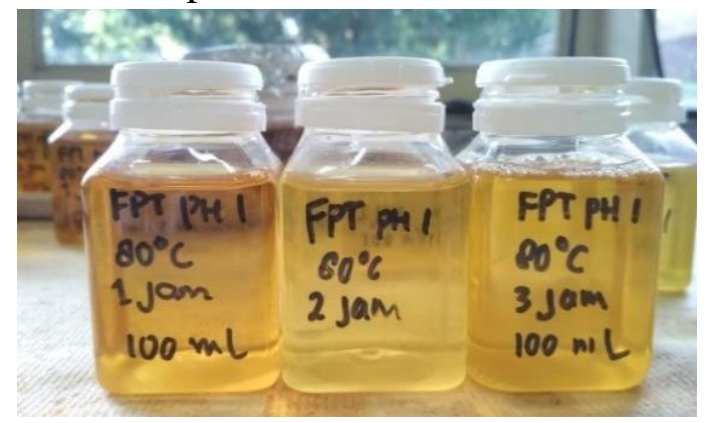

Gambar 5. Filtrat pelarutan total parameter waktu.
Filtrat pelarutan total parameter waktu berwarna kuning, namun terdapat perbedaan kejernihan pada waktu yang berbeda. Filtrat pelarutan total dengan waktu 2 jam menghasilkan warna kuning cerah dan jernih, kemungkinan disebabkan oleh keberadaan uranium yang dominan pada kondisi waktu tersebut karena ion uranil berwarna kuning dan stabil dalam larutan asam[16]. Perbedaan warna filtrat juga dipengaruhi oleh perbedaan unsur uranium, torium, dan logam tanah jarang yang berada dalam larutan, seperti yang ditunjukkan pada Gambar 6.

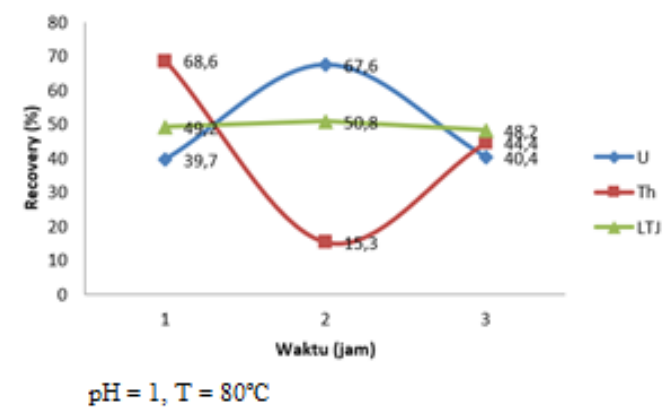

Grafik 3. Hasil recovery uranium, torium, dan logam tanah jarang pada filtrate pelarutan total parameter waktu

Semakin lama waktu pelarutan menyebabkan kontak antara zat terlarut dan pelarut semakin lama, sehingga unsur dapat terlarut dengan sempura. Hal ini terjadi pada uranium dan logam tanah jarang pada filtrat pelarutan total 1 jam dan 2 jam yang mengalami peningkatan recovery seiring dengan meningkatnya waktu. Lamanya waktu juga dapat mempengaruhi banyaknya pelarut yang menguap, sehingga volume pelarut yang beraksi dengan unsur-unsur dalam endapan menjadi berkurang. Hal ini menyebabkan pada waktu pelarutan total 3 jam persentase recovery uranium dan logam tanah jarang menurun. Torium mengalami penurunan recovery yang signifikan pada pelarutan total 2 jam. Oleh karena itu, berdasarkan pengamatan variasi waktu, uranium, torium 
dan LTJ dapat terlarut pada kondisi pelarutan total selama 2 jam. Setelah didapatkan kondisi optimal pelarutan yang dapat melarutkan uranium, torium, dan LTJ dalam endapan, selanjutnya adalah tahap pemisahan unsurunsur tersebut dengan metode pengendapan.

Proses pengendapan menggunakan $\mathrm{NH}_{4} \mathrm{OH}$ sebagai reagen. $\mathrm{NH}_{4} \mathrm{OH}$ dipilih sebagai reagen pengendapan karena penanganan hasil samping reaksi dengan unsur dalam filtrat pelarutan lebih mudah dilakukan [5]. Hasil samping yang berupa $\mathrm{NH}_{4} \mathrm{Cl}$ dapat dihilangkan dengan proses pemanasan, menghasilkan gas $\mathrm{NH}_{3}$ dan $\mathrm{Cl}_{2}$. Jika menggunakan basa lainnya seperti $\mathrm{NaOH}$, hasil samping reaksi $\mathrm{NaOH}$ dengan unsur dalam endapan berupa $\mathrm{NaCl}$ akan menjadi pengotor dan perlu pengolahan lebih lanjut untuk menghilangkan $\mathrm{Na}$ dari endapan [5].

Parameter pengendapan yang diamati pada penelitian ini berupa $\mathrm{pH}$. Setiap unsur memiliki $\mathrm{pH}$ yang selektif sehingga dapat digunakan untuk memisahkan unsur tersebut dari larutan menjadi bentuk endapan seperti pada Gambar 4.

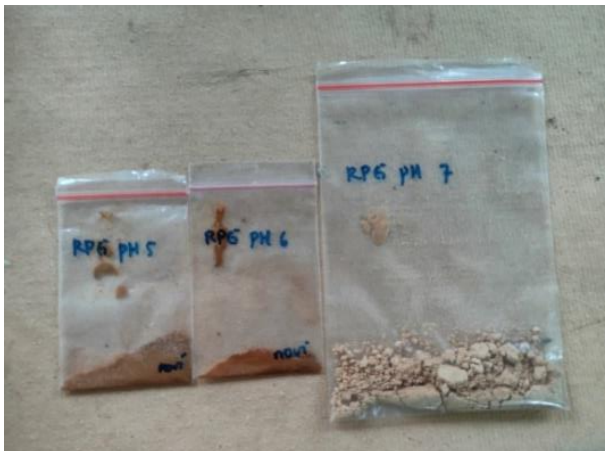

Gambar 6. Residu pengendapan parameter pH 5, 6, 7.

Residu pengendapan parameter $\mathrm{pH}$ menghasilkan kuantitas dan warna yang berbeda pada setiap $\mathrm{pH}$. Perbedaan sifat fisik pada residu dipengaruhi oleh kadar unsur yang diperoleh pada proses pengendapan. Faktor yang mempengaruhi perbedaan antara residu pengendapan $\mathrm{pH} 5$ dan $\mathrm{pH} 6$ adalah kadar unsur uranium dan torium. Residu pengendapan pada $\mathrm{pH} 6$ memiliki kadar uranium lebih banyak dibandingkan pada $\mathrm{pH}$ 5. Residu pengendapan pada $\mathrm{pH} 7$ berwarna putih kekuningan mengindikasikan keberadaan logam tanah jarang yang paling dominan dibandingan dengan unsur radioaktifnya, dalam hal ini logam tanah jarang yang paling dominan adalah cerium yang berwarna kuning pucat [17]. Keberadaan uranium, torium, dan logam tanah jarang di dalam endapan pada masing-masing $\mathrm{pH}$ disajikan dalam bentuk grafik pada Gambar 8 .

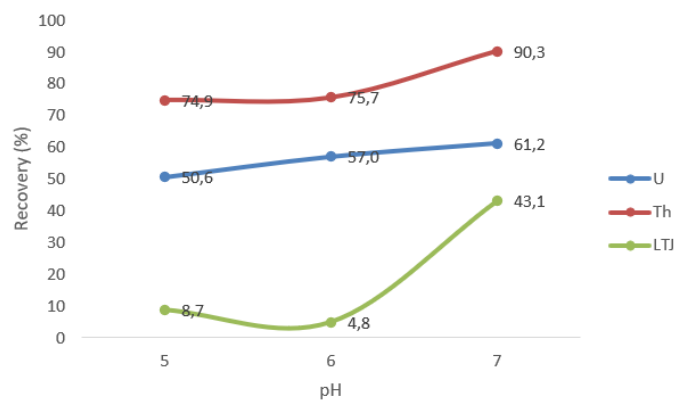

Gambar 8 Hasil recovery uranium, torium, dan logam tanah jarang pada residu pengendapan.

Semakin tinggi $\mathrm{pH}$ maka semakin tinggi recovery uranium, torium, dan logam tanah jarang. Uranium yang mengendap merupakan uranium dalam bentuk $\mathrm{UO}_{2}(\mathrm{OH})_{2}$ dengan valensi 6. Pengendapan uranium (VI) terjadi pada kisaran pH 5,5-7,0. Pengaruh keasaman torium pada kisaran $\mathrm{pH}$ 6-7 menunjukkan nilai kelarutan yang sangat kecil [18], sehingga torium mengendap pada $\mathrm{pH}$ tersebut. Logam tanah jarang membentuk hidroksida $\mathrm{RE}(\mathrm{OH})_{3}$ fase padat dan akan meningkat dengan peningkatan $\mathrm{pH}$ [14]. $\mathrm{pH}$ pengendapan dari logam tanah jarang hidroksida (kecuali skandium) berada pada kisaran $\mathrm{pH}$ 6,8-8,0 dalam media klorida dan sulfat [19]. Meski persentase recovery uranium, torium, dan logam tanah jarang meningkat seiring dengan meningkatnya $\mathrm{pH}$, namun perlu diperhatikan bahwa pada $\mathrm{pH} 6$ persentase recovery logam tanah jarang menurun, sedangkan persentase 
recovery uranium dan torium semakin meningkat. Oleh karena itu, $\mathrm{pH}$ yang optimal untuk pemisahan unsur radioaktif dari logam tanah jarang adalah $\mathrm{pH} 6$.

\section{KESIMPULAN}

Kondisi optimal pelarutan total menggunakan $\mathrm{HCl}$ tercapai pada $\mathrm{pH} 1$, suhu pelarutan $80^{\circ} \mathrm{C}$, dan waktu pelarutan selama 2 jam. Persentase terbesar yang dihasilkan pada proses pelarutan total dari masing-masing unsur adalah $67,6 \%$ uranium, 15,3\% torium, dan 50,8\% logam tanah jarang. Kondisi optimal pengendapan menggunakan $\mathrm{NH}_{4} \mathrm{OH}$ untuk memisahkan unsur radioaktif dan logam tanah jarang diperoleh pada $\mathrm{pH}$ 6. Persentase masing-masing unsur pada kondisi tersebut yaitu $57 \%$ uranium, $75,7 \%$ torium, $4,8 \%$ logam tanah jarang.

\section{UCAPAN TERIMA KASIH}

Terima kasih penulis ucapkan kepada staff Teknologi Penambangan dan Pengolahan PTBGN-BATAN dan semua pihak yang terlibat selama penelitian ini berlangsung.

\section{DAFTAR PUSTAKA}

[1] M. Purwani, S. Suyanti, dan D. Husnurrofiq, "Optimasi dan Kinetika Memakai $\mathrm{NaOH}$," in Prosiding Pertemuan dan Presentasi Ilmiah Penelitian Dasar Ilmu Pengetahuan dan Teknologi Nuklir, 2015, pp. 9-17.

[2] K. Trinopiawan dan S. Sumiarti, "Pemisahan Thorium dari Uranium pada Monasit dengan Metode Pengendapan," J. Eksplorium, vol. 33, no. 1, pp. 55-62, 2012.

[3] H. L. Nuri, R. Faizal, W. Sugeng, S. Budi, dan S. Arif, "Pengolahan Monasit Dari Limbah Penambangan Timah: Pemisahan Logam Tanah Jarang (RE) Dari U Dan Th," Pros. Present. Ilm. Daur Bahan Bakar Nukl. V, pp. 54-60, 2000.

[4] S. Sumarni, R. Prassanti, K. Trinopiawan, S. Sumiarti, dan H. L. Nuri, "Penentuan Kondisi Pelarutan Residu dari Hasil Pelarutan Parsial Monasit Bangka," J. Eksplorium, vol. 32, no. 2, pp. 115-124, 2011.

[5] M. Anggraini, B. Sarono, S. Waluyo, R. Rusydi, dan S. Sujono, "Pengendapan Uranium dan
Thorium Hasil Pelarutan Slag II," Eksplorium, vol. 36, no. 2, p. 125, 2015.

[6] S. Tjokrokardono, B. Soetopo, dan Ngadenin, "Tinjauan Sumber Daya Monasit di Indonesia Sebagai Pendukung Litbang/Industri Superkonduktor," in Seminar IPTEK Nuklir dan Pengelolaan Sumber Daya Tambang, 2002.

[7] R. Subagja, K. P. Serpong, dan T. Selatan, "Monasite Bangka dan Alternatif Proses," 2014.

[8] M. V Purwani, "Pengendapan torium dari hasil olah pasir monasit," pp. 147-154, 2011.

[9] Isyuniarto, A. Muhadi, dan H. Tri, "Pelindian Pasir Monasit dengan Metode Basa," Pros. Perlemuan dan Present. Ilm., vol. 132, no. 132-136, 1999.

[10] H. L. Nuri, R. Faizal, Susilaningtyas, S. Waluyo, dan Rifandriyah Ar, "Aplikasi Perlatan Proses Monasit Skala Laboratorium untuk Pengolahan Monasit Bangka Menjadi Rare Earth Oksida dengan Kapasitas $1 \mathrm{Kg} /$ Hari," in Prosiding Seminar Geologi Nuklir dan Sumberdaya Tambang, 2004, pp. 114-124.

[11] R. Subagja, "Monasite Bangka dan Alternatif Proses Pengolahannya," Majalah Metalurgi, Tangerang Selatan, 2014.

[12] A. C. Neish, "Preparation of Pure Cerium Salts and The Color of Cerium Oxide," Am. Chem. Soc., vol. XXXI, no. 5, 1909.

[13] T. Fujino, I. Grenthe, J. Droz, E. C. Buck, T. E. A. Schmitt, dan S. F. Wolf, "URANIUM *," 1948.

[14] E. Kim dan K. Osseo-Asare, "Hydrometallurgy Aqueous stability of thorium and rare earth metals in monazite hydrometallurgy : $\mathrm{Eh}-\mathrm{pH}$ diagrams for the systems $\mathrm{Th}-, \mathrm{Ce}-, \mathrm{La}-, \mathrm{Nd}-(\mathrm{PO} 4)-$ ( SO 4 ) - H $2 \mathrm{O}$ at $25^{\circ} \mathrm{C}$," Hydrometallurgy, vol. 113-114, pp. 67-78, 2012.

[15] M. Anggraini dan I. Kris Murwani, "Pemisahan Unsur Radioaktif dan Logam Tanah Jarang dalam Terak Timah dengan Fusi Alkali dan Pelindian Asam," Pros. Semin. Nas. Kebumian XII, vol. 1, pp. 4-5, 2016.

[16] E. H. Borai, M. S. A. El-ghany, I. M. Ahmed, M. M. Hamed, A. M. S. El-din, dan H. F. Aly, "Modified Acidic Leaching for Selective Separation of Thorium, Phosphate and Rare Earth Concentrates from Egyptian Crude Monazite," Int. J. Miner. Process., 2016.

[17] T. Wahyudi, "Reviewing The Properties Of Rare Earth Element-Bearing Minerals, Rare Earth Elements and Cerium Oxide Compound," vol. 18, no. 2, pp. 92-108, 2015.

[18] S. Higashi, "Determination of the Solubility of Thorium Hydroxide," Bull. Inst. Chem. Res. Kyoto Univ., vol. 37, no. 3, pp. 200-206, 1959.

[19] Z. Zhu, Y. Pranolo, dan C. Y. Cheng, "Separation of uranium and thorium from rare earths for rare earth production - A review," Miner. Eng., vol. 77, pp. 185-196, 2015. 